\title{
Findings from the Condition Surveys Conducted by the University of Kansas Libraries
}

\section{Brian J. Baird, Jana Krentz, and Brad Schaffner}

\begin{abstract}
As part of establishing a strategic plan for preservation at the University of Kansas (KU) Libraries, a task force was organized to conduct two collection condition surveys. One survey focused on materials returning from circulation, and the other looked at the general collections. Materials returning from circulation were surveyed to determine their condition because most preservation efforts at KU are "use" driven. The survey of the entire collection shed light on the physical condition of KU's overall holdings. This information aided in long-term preservation planning. Survey data from the more than 4,000 volumes were entered directly into a computer database using laptop computers. This facilitated quick data entry, improved the accuracy of the information, and made data analysis easier. The results of the survey have had farreaching effects in determining library policy, from influencing a decision to switch to a paperback-preferred purchasing policy, to increasing awareness of space and facility concerns throughout the libraries, to heightening user awareness of preservation issues.
\end{abstract}

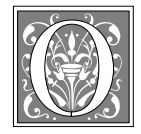

ne of the greatest challenges facing academic and research libraries today is the preservation of collections. The majority of materials housed in research libraries are unique and irreplaceable. Unfortunately, the number of these items needing preservation treatment far exceeds the availability of resources. Therefore, libraries must carefully evaluate the conditions of their collections and use that information to develop proactive preservation plans.
As part of developing a strategic plan for preserving their collections, in the spring of 1996 the University of Kansas (KU) Libraries ${ }^{1}$ organized a task force to perform two condition surveys of their general collections. The first survey evaluated materials returning from circulation, and the second examined volumes in the stacks. Condition surveys are common in research libraries, and the findings at the KU Libraries will contribute to the increasing pool of information on the conditions of the nation's research

Brian J. Baird is Preservation Librarian at the University of Kansas Libraries; e-mail: bbaird@ukans.edu. Jana Krentz is Ibero-American Bibliographer at the University of Kansas Libraries; e-mail: jkrentz@ukans.edu. Brad Schaffner is Russian Studies Librarian at the University of Kansas Libraries; e-mail: bschaffn@ukans.edu. 
collections. The method of data collection and the contrast in results between the circulation returns and stacks surveys provide unique and significant information of value to other research libraries.

\section{Procedures for Conducting the Surveys}

Although all the libraries' collections were sampled, the circulation return survey was conducted for the entire library system. This allowed the task force to limit the survey to 495 items, which provided a statistically significant sample large enough to report on the condition of materials returning from circulation at the KU Libraries as a whole. However, it did not provide sufficient information to draw conclusions about the condition of circulation returns of individual libraries.

Data on circulation returns were collected at each library using the following methodology. The day before the task force was scheduled to survey materials, one of its members coordinated with that

\section{A minimum sample size of $\mathbf{3 5 0}$ volumes was required to reliably predict collection conditions in each individual library.}

library's circulation staff to set aside all items returning from circulation. On the day of the survey, the task force randomly selected the required number of samples from the circulation returns and surveyed the volumes. Upon completion of the circulation condition survey, the task force met to discuss the process before proceeding with the stack survey. This ensured that the stack survey would be conducted in a similar manner by all the task force members.

With 3,679 volumes evaluated, the stacks survey was, by far, the largest segment of the task force's work. A stratified sampling technique was used to guarantee that the information collected at each library would be statistically significant. A minimum sample size of 350 volumes was required to reliably predict collection conditions in each individual library. Much larger samples were taken from the collections of the Science and Watson libraries which house a majority of the overall collections. This stratification technique ensured that data from the larger libraries held the same weight as did data from the smaller ones.

For the second survey, sample items were randomly selected from the stacks. The formula for identifying sample items is as follows:

$\mathrm{n}=$ number of shelves in a location

$\div$ number of sample items needed

Counting from the left side of the shelf, the surveyor sampled the fourth volume from every $\mathrm{n}^{\text {th }}$ shelf. If there was no fourth volume on the shelf, the first available volume to the left was selected. If there were no volumes on the shelf, the next available shelf holding volumes was used. To guarantee that all volumes had an equal chance of being selected, the sampling technique involved counting shelves rather than ranges because many of the stacks have differing numbers of shelves per range.

Rather than moving from book to book in the stacks when surveying materials, the most efficient way to conduct the survey was to pull the volumes from the stacks and move them to a work area for evaluation. A flag recorded the shelving condition for each item. Although this proved to be an efficient method for the task force, it required the libraries' various shelving units to reshelve the sampled materials. With nearly 3,700 items needing to be reshelved as a result of the survey, this represented a major commitment in all libraries. The process went smoothly because the task force members made great efforts to coordinate their activities with appropriate staff. 


\section{Survey Instrument}

One goal of the survey was to provide the staff of the preservation department with information on the status of the collections. With this in mind, and after reviewing other preservation surveys published in the library literature, the task force created a survey instrument that would provide information on the condition of the KU Libraries' collections. The task force created a twenty-question survey instrument composed of eighteen required responses and two optional responses.

The required portion of the survey had scripted answers from which the task force members could choose the most appropriate response. These scripted responses made the data easy to analyze. For the eighteen required questions, there were 145 scripted answers from which to choose. As a result, this complex questionnaire yielded a great deal of information about each evaluated volume. The two optional questions in the survey were free-text fields. The first allowed the surveyor to enter call numbers into the database for items needing immediate preservation treatment or further analysis. The second was a note field into which additional information could be entered. One question - about "shelving condition" - was used only in the stacks survey. A listing of the questions and scripted answers can be found in Table 1.

All survey information was input directly into a database created on Microsoft Access using a specially designed form. In order to answer the first eleven questions, the surveyor selected responses from pull-down menus. The form was designed so that each of these questions had to be answered before the record would be accepted into the database. This ensured that questions were not accidentally missed during the survey process.

A small dialog box appeared at the bottom of the computer screen that gave specific, brief, explanatory text for each question and answer. The text appeared when a question or answer was selected. This explanatory text allowed task force members to answer questions in a consistent manner. Besides making the surveying process easier, entering data directly into the database eliminated the additional step of converting data recorded on paper to machine-readable form. This also facilitated analysis of the information collected because no significant restructuring of the data was required.

Much of the information about the KU Libraries' collections could be gathered only because of the computer technology available. Use of Microsoft Access made it possible to design a data-entry form that was easy to use; instructive to the surveyor (e.g., dialog box that linked terms to definitions); ensured clean, accurate data; and saved the task force significant inputting time. Recording the information about each volume as an individual record provided a great deal of freedom in how the data could be manipulated. The flexibility of the database to yield itself to analysis continues to prove very useful in answering many questions about the KU Libraries' collections that the task force did not anticipate at the time the survey instrument was created. This greatly increases the value of the collected data.

\section{Analysis of the Data}

Table 1 shows the complete results for both the circulation and the stacks surveys. One should note the contrast in results between data from the circulation survey and data from the combined stacks survey. The vast majority of the data gathered in these surveys are nominal data, which limits the kind of statistical analysis that can be performed. The Chi-squared test for significance was used to compare the results from the combined stacks and circulation surveys in order to determine which differences in results were significant at the twotailed, .05 significance level. 
TABLE 1

Results of Circulation and Stacks Surveys

\begin{tabular}{|c|c|c|c|}
\hline & $\begin{array}{l}\text { Combined } \\
\text { Stacks }\end{array}$ & Circulation & $\begin{array}{c}X^{2} \\
\text { Test }\end{array}$ \\
\hline Sample Size & 3,679 & 495 & \\
\hline $\begin{array}{l}\text { Size of Volume } \\
\quad \text { Regular } \\
\text { Folio } \\
\text { Oversized }\end{array}$ & $\begin{array}{l}93.59 \% \\
5.38 \\
1.03\end{array}$ & $\begin{array}{l}94.34 \% \\
5.66 \\
0\end{array}$ & $\begin{array}{l}0.01 \\
0.01 \\
1.03\end{array}$ \\
\hline $\begin{array}{l}\text { Type of Volume } \\
\text { Monograph } \\
\text { Part of multivolume set } \\
\text { Serial } \\
\text { Scores }\end{array}$ & $\begin{array}{l}45.58 \% \\
18.78 \\
33.16 \\
2.47\end{array}$ & $\begin{array}{l}73.13 \% \\
9.7 \\
15.56 \\
1.62\end{array}$ & $\begin{array}{l}16.65 \% * \\
4.39 * \\
9.34 * \\
0.29\end{array}$ \\
\hline $\begin{array}{l}\text { Leaf Attachment } \\
\text { Sewn through the fold } \\
\text { Oversewn } \\
\text { Adhesive bound } \\
\text { Stapled through the fold } \\
\text { Side-sewn or stapled } \\
\text { Spiral or other loose sheet binding }\end{array}$ & $\begin{array}{l}47.21 \% \\
16.06 \\
29.71 \\
3.7 \\
2.39 \\
0.92\end{array}$ & $\begin{array}{l}43.64 \% \\
7.68 \\
44.24 \\
3.64 \\
0.4 \\
0.4\end{array}$ & $\begin{array}{l}0.27 \% \\
4.37 * \\
7.11^{*} \\
0.00 \\
1.66 \\
0.29\end{array}$ \\
\hline $\begin{array}{l}\text { Condition of Text Block (mark all that apply) } \\
\text { In good condition } \\
\text { Remain in stacks** } \\
\text { Broken or loose sewing or adhesive } \\
\text { Broken text block } \\
\text { Loose pages } \\
\text { Damaged pages (not mutilation) } \\
\text { Missing pages (not mutilation) } \\
\text { Pages damaged or curled from lack of support } \\
\text { (paperbacks) }\end{array}$ & $\begin{array}{l}90.84 \% \\
3.59 \\
3.4 \\
1.55 \\
1.9 \\
2.88 \\
0.08 \\
0.73\end{array}$ & $\begin{array}{l}88.48 \% \\
7.47 \\
2.83 \\
1.62 \\
5.05 \\
3.23 \\
0 \\
0.81\end{array}$ & $\begin{array}{l}0.06 \\
4.19 * \\
0.10 \\
0.00 \\
5.22 * \\
0.04 \\
0.08 \\
0.01\end{array}$ \\
\hline $\begin{array}{l}\text { Gutter Margin Width } \\
\text { Less than } 1 / 2 \text { inch } \\
\text { More than } 1 / 2 \text { inch, but less than } 3 / 4 \text { inch } \\
\text { More than } 3 / 4 \text { inch, but less than } 1 \text { inch } \\
1 \text { inch or more }\end{array}$ & $\begin{array}{l}37.84 \% \\
39.28 \\
14.46 \\
8.43\end{array}$ & $\begin{array}{l}37.58 \% \\
43.84 \\
14.34 \\
4.24\end{array}$ & $\begin{array}{l}0.00 \\
0.53 \\
0.00 \\
2.08\end{array}$ \\
\hline $\begin{array}{l}\text { Paper pH (Abbey Pen) } \\
\text { Yellow or clear (acidic) } \\
\text { Tan (slightly acidic) } \\
\text { Purple (alkaline) }\end{array}$ & $\begin{array}{l}65.78 \% \\
10.66 \\
23.57\end{array}$ & $\begin{array}{c}50.3 \% \\
6.57 \\
47.83\end{array}$ & $\begin{array}{l}3.64 * \\
1.57 \\
24.97 *\end{array}$ \\
\hline $\begin{array}{l}\text { Paper Fold Test (paper breaks after) } \\
\text { Less than } 1 \text { fold } \\
\text { Less than } 1 \text { double-fold } \\
\text { Less than } 2 \text { double-folds }\end{array}$ & $\begin{array}{l}1.85 \% \\
2.56 \\
1.58\end{array}$ & $\begin{array}{l}0.2 \% \\
1.21 \\
0\end{array}$ & $\begin{array}{l}1.47 \\
0.71 \\
1.58\end{array}$ \\
\hline $\begin{array}{l}* \mathrm{P}=\text { or }<.05 \text { (two-tailed) } \\
* * \text { Item is beginning to weaken but is not damaged enough }\end{array}$ & (2) & & ontinued \\
\hline
\end{tabular}




\begin{tabular}{|c|c|c|c|}
\hline \multicolumn{4}{|c|}{$\begin{array}{c}\text { TABLE 1, cont. } \\
\text { Results of Circulation and Stacks Surveys }\end{array}$} \\
\hline & \multicolumn{2}{|c|}{ Combined } & $\begin{array}{c}X^{2} \\
\text { Test }\end{array}$ \\
\hline Less than 3 double-folds & 3.72 & 3.43 & 0.02 \\
\hline More than 3 double-folds & 90.3 & 95.15 & 0.26 \\
\hline \multicolumn{4}{|l|}{ Paper Condition (mark all that apply) } \\
\hline White and strong & $62.11 \%$ & $76.97 \%$ & 3.56 \\
\hline Yellowish or tan & 32.7 & 20.2 & $4.78 *$ \\
\hline Brown & 5.05 & 2.63 & 1.16 \\
\hline Glossy or coated & 13.92 & 19.8 & 2.48 \\
\hline Calendered & 2.77 & 0.4 & 2.03 \\
\hline Ground wood paper & 4.27 & 3.03 & 0.36 \\
\hline Pest damaged & 0 & 0 & \\
\hline Volume indicates it is printed on acid-free paper & 2.53 & 10.1 & $22.65^{*}$ \\
\hline \multicolumn{4}{|l|}{ Mutilation and Patron Damage (mark all that apply) } \\
\hline Total volumes mutilated & $19.76 \%$ & $31.11 \%$ & $6.52 *$ \\
\hline Pencil & 9.98 & 16.36 & $4.08 *$ \\
\hline Ink & 4.92 & 9.49 & $4.24 *$ \\
\hline Highlighter & 0.79 & 3.64 & $10.28 *$ \\
\hline Paper clips & 0.16 & 1.41 & $9.77 *$ \\
\hline Dog-ears & 4.29 & 10.1 & $7.87 *$ \\
\hline Post-it notes & 0.24 & 0.61 & 0.57 \\
\hline Bookmarks left in the volume & 2.72 & 3.43 & 0.19 \\
\hline Pages torn or cut out & 0.57 & 0.4 & 0.05 \\
\hline Animal damage & 0.02 & 0 & 0.02 \\
\hline Pages or cover stained with food, drink, or water & 5.71 & 9.29 & 2.24 \\
\hline \multicolumn{4}{|l|}{ Type of Binding } \\
\hline Publisher binding & $46.67 \%$ & $50.3 \%$ & 0.28 \\
\hline Publisher paper binding & 12.69 & 18.79 & 2.93 \\
\hline Pamphlet & 4.54 & 3.64 & 0.18 \\
\hline Commercial case binding & 32.26 & 23.84 & 2.20 \\
\hline Commercial mylar binding & 3.83 & 3.43 & 0.04 \\
\hline \multicolumn{4}{|l|}{ Condition of Binding (mark all that apply) } \\
\hline In good condition & $85.7 \%$ & $84.85 \%$ & 0.01 \\
\hline Remain in stacks** & 8.94 & 9.49 & 0.03 \\
\hline Damaged spine & 5.68 & 6.26 & 0.06 \\
\hline Loose joints & 4.48 & 6.67 & 1.07 \\
\hline Damaged inner joints & 4.4 & 3.84 & 0.07 \\
\hline Damaged paper cover & 1.28 & 3.84 & $5.12 *$ \\
\hline Cover off volume & 0.76 & 1.82 & 1.48 \\
\hline Red-rot leather & 1.11 & 0.2 & 0.75 \\
\hline Title worn off & 0.9 & 1.01 & 0.01 \\
\hline Title label missing & 0.33 & 0 & 0.33 \\
\hline \multicolumn{4}{|c|}{$\begin{array}{l}* \mathrm{P}=\text { or }<.05 \text { (two-tailed) } \\
* * \text { Item is beginning to weaken, but is not damaged enough to warrant treatment. } \\
\text { continued }\end{array}$} \\
\hline
\end{tabular}


TABLE 1, cont.

Results of Circulation and Stacks Surveys

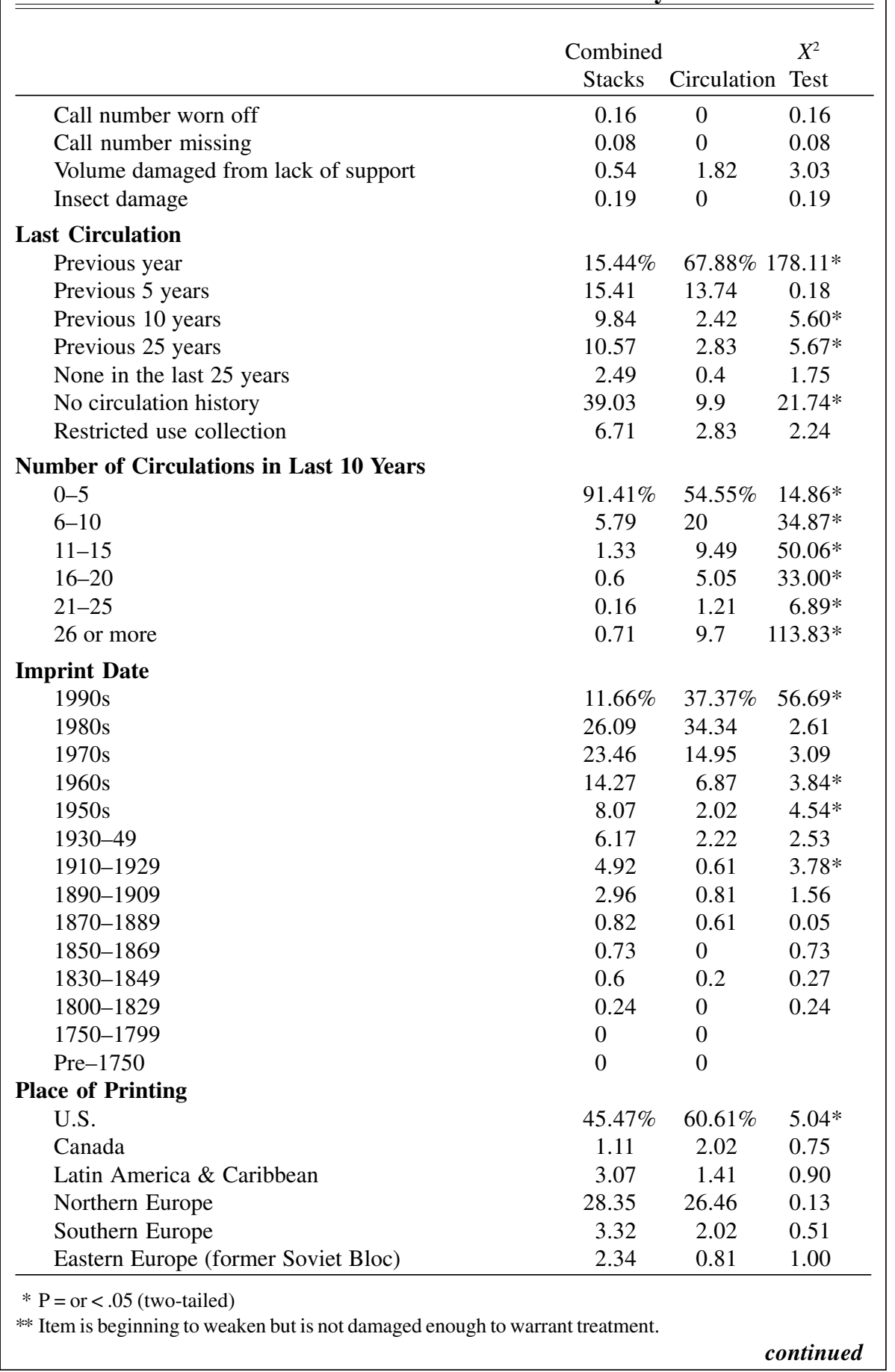


TABLE 1, cont.

Results of Circulation and Stacks Surveys

\begin{tabular}{|c|c|c|c|}
\hline & $\begin{array}{c}\text { Combined } \\
\text { Stacks }\end{array}$ & Circulation & $\begin{array}{c}X^{2} \\
\text { Test }\end{array}$ \\
\hline Former USSR & 3.4 & 0.2 & 3.01 \\
\hline Central Africa & 0 & 0.4 & \\
\hline South Africa & 0.08 & 0.61 & 3.51 \\
\hline Northern Africa (Arabic States) & 0.14 & 0 & 0.14 \\
\hline Middle East & 0.16 & 0 & 0.16 \\
\hline India & 0.49 & 0.2 & 0.17 \\
\hline Central Asia & 0.11 & 0 & 0.11 \\
\hline China and Far East (not Japan) & 7.2 & 2.63 & 2.90 \\
\hline Japan & 4.46 & 2.63 & 0.75 \\
\hline Australia/New Zealand & 0.3 & 0 & 0.30 \\
\hline \multicolumn{4}{|c|}{ Previous Preservation Treatments (mark all that apply) } \\
\hline Total volumes treated & $9.08 \%$ & $4.65 \%$ & 2.16 \\
\hline Damaged or missing pages replaced & 0.38 & 0 & 0.38 \\
\hline Been repaired in-house & 5.87 & 2.83 & 1.57 \\
\hline In acidic box & 0.27 & 0 & 0.27 \\
\hline In acidic pamphlet binder & 3.7 & 1.01 & 1.96 \\
\hline In acidic paper envelope & 0 & 0 & \\
\hline Volume tied together with string & 0.03 & 0 & 0.03 \\
\hline In acid-free box & 0.22 & 0.2 & 0.00 \\
\hline In acid-free pamphlet binder & 0.82 & 0.61 & 0.05 \\
\hline In acid-free envelope & 0.08 & 0 & 0.08 \\
\hline Been reformatted & 0 & 0 & \\
\hline \multicolumn{4}{|l|}{ Shelving Condition (mark all that apply) } \\
\hline Shelved correctly & $86.27 \%$ & N/A & \\
\hline Shelved too tightly & 5.22 & N/A & \\
\hline Not shelved straight & 3.56 & N/A & \\
\hline Shelved on fore-edge & 1.49 & N/A & \\
\hline Shelved on spine & 0.19 & N/A & \\
\hline Shelved in wrong location & 3.51 & N/A & \\
\hline \multicolumn{4}{|c|}{ Treatment Decision for Volume (mark all that apply) } \\
\hline In good condition & $83.28 \%$ & $78.79 \%$ & 0.24 \\
\hline Send to stacks as-is** & 10.06 & 12.12 & 0.42 \\
\hline Needs commercial binding & 2.06 & 4.24 & 2.31 \\
\hline Needs in-house repair & 0.71 & 3.69 & $12.51 *$ \\
\hline Needs conservation treatment & 0.6 & 0.4 & 0.07 \\
\hline Send to brittle book processing & 0.62 & 1.01 & 0.25 \\
\hline Place in enclosure & 0.35 & 0 & 0.35 \\
\hline
\end{tabular}


The results in table 1 lend credence to the maxim that 20 percent of a research library's collections receive 80 percent of the use. The data indicate that the volumes from the circulation survey are borrowed more often and had higher total numbers of circulations than those from the combined stacks condition survey. Analysis also shows that newer materials are lent more often than older materials, with nearly 72 percent of all circulating items having been printed in the 1980s or 1990s.

\section{Paper Condition}

The importance of paper condition cannot be understated because it is one of the primary factors in determining what type of preservation treatment can be performed on a volume. If the paper is strong enough to withstand treatment, most bound volumes can be successfully, and often economically, rebound. However, if the paper in the volume is brittle, ${ }^{2}$ it will not have the strength to withstand rebinding or future use, and thus must be reformatted to preserve the information-an expensive and labor-intensive process.

Attention to brittle paper has become a national preservation issue. Many programs have been established in research libraries in an effort, as the charge for the Commission on Preservation and Access

\section{The task force decided to evaluate if some leaf attachment methods proved superior to others.}

states, to "develop and encourage collaborative strategies for preserving and providing access to the accumulated human record." ${ }^{3}$ These programs were initiated as libraries and archives discovered that approximately a quarter of their collections were embrittled. The libraries at Yale University ${ }^{4}$ and the University of Illinois at Urbana-Champaign ${ }^{5}$ found that more than 25 percent of their collections had embrittled paper. Syracuse University discovered that more than 12 percent of its collections are brittle. ${ }^{6}$

A collection's percentage of embrittled paper is dependent on a number of factors, including climate, environmental controls in the library building, and the nature of the collection (for example, large collections of publications from lessdeveloped regions of the world). Compared to the proportion of embrittled volumes found in other large research libraries, the KU Libraries were encouraged to find that the condition surveys indicated that only six percent of their holdings have embrittled paper. This is relatively good news, given the high cost of reformatting embrittled materials. Like many large research libraries, more than 47 percent of all brittle materials in KU's general collections do not circulate often. This will help increase the life of these materials. However, eventually these items will need some kind of treatment if they are to be saved, and looming on the horizon is the fact that 65 percent of the collections are printed on acidic paper that will, in time, become brittle.

The good news for libraries, archives, and scholars is that most books published in the United States and Northern Europe $^{7}$ are now printed on alkaline, or acidfree paper. ${ }^{8}$ Acid-free paper, made in accordance with the ANSI Z39.48-1992 standard for "Permanency of Paper Printed Library Materials," will last several hundred years. Changes in environmental laws in the 1980s forcing papermakers to produce less harmful wastes motivated them to produce alkaline paper, a more environment-friendly product. These laws, combined with strong concerns expressed by the library and archive communities, have resulted in KU's finding that 81 percent of all of its 1990 imprints from the United States and Northern Europe being printed on acid-free paper. The United States and Northern Europe are singled out because 75 percent of all volumes bearing a 1990 imprint that were 


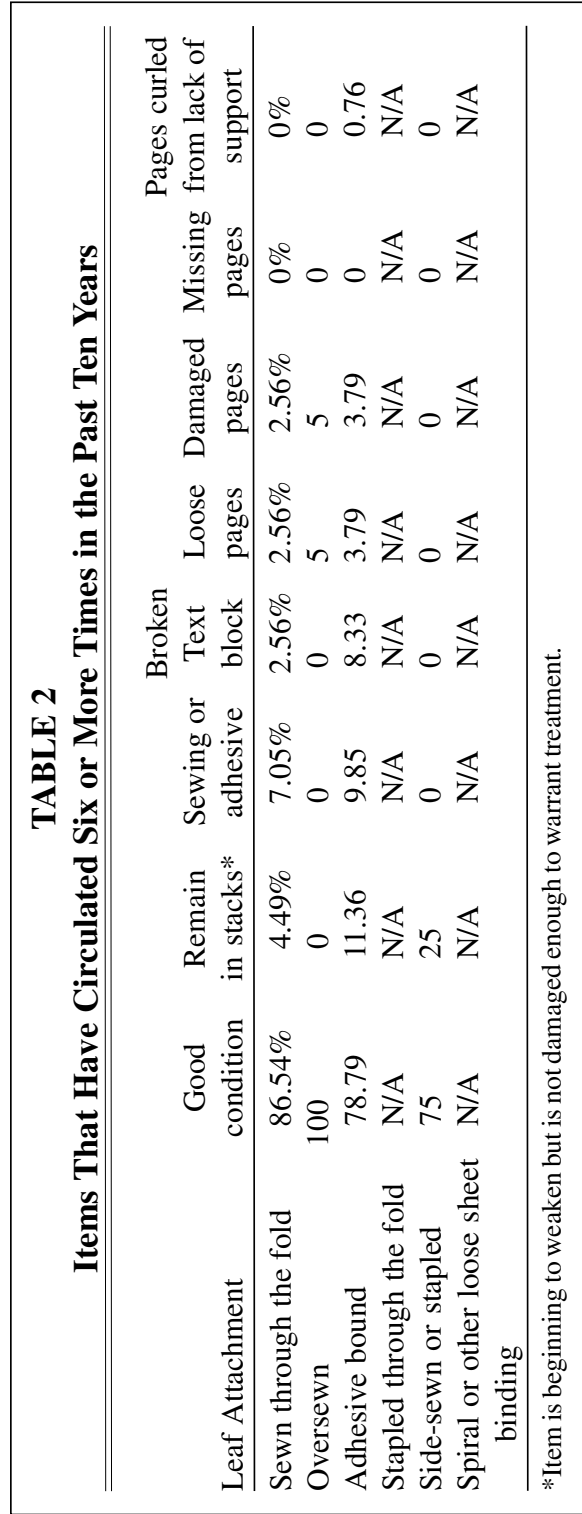

acquired by KU Libraries came from these world regions.

\section{Text Block Conditions}

A bound volume is made up of two parts - the text block and the cover. Data from the surveys relating to each of these parts will be looked at in turn. These two components were considered separately when collecting data for the surveys because the physical integrity of volumes fail for different reasons, depending on the construction of their text blocks and covers.

Paper, discussed previously, is the primary component of a text block. Next, one must consider the leaf attachment, or how the pages of the text block are held together. The task force decided to evaluate if some leaf attachment methods proved superior to others. As table 1 shows, most leaf attachment methods hold up well in the stacks; the only real exceptions are spiral and other loosebound text blocks, and side-sewn or stapled volumes. By conducting analysis on only those volumes that have circulated six or more times in the past ten years, one finds that items sewn through the fold wear better than those that are adhesive bound (see table 2).

There are significant differences in the quality of adhesive binding methods used by publishers and commercial binders. Many publishers use hot-melt adhesives that dry very quickly and usually are quite stiff and brittle. Commercial binders use a cold adhesive and a doublefan binding method-meaning that loose leaves are fanned to each side during the gluing process to allow a small amount of adhesive to adhere itself to the sides of each page, which greatly improves adhesion. These cold, polyvinyl acetate (PVA) adhesives dry slowly, are strong, and remain flexible for many years. Therefore, to truly determine how adhesive-bound text blocks hold up to use, publishers and commercial bindery adhesive bindings were analyzed separately, and the results are given in table 3.

A higher percentage of materials that are adhesive bound by commercial binders are in good condition compared to those that are adhesive bound as part of a publisher binding. However, these differences are not statistically significant. Analysis of only those adhesive-bound 


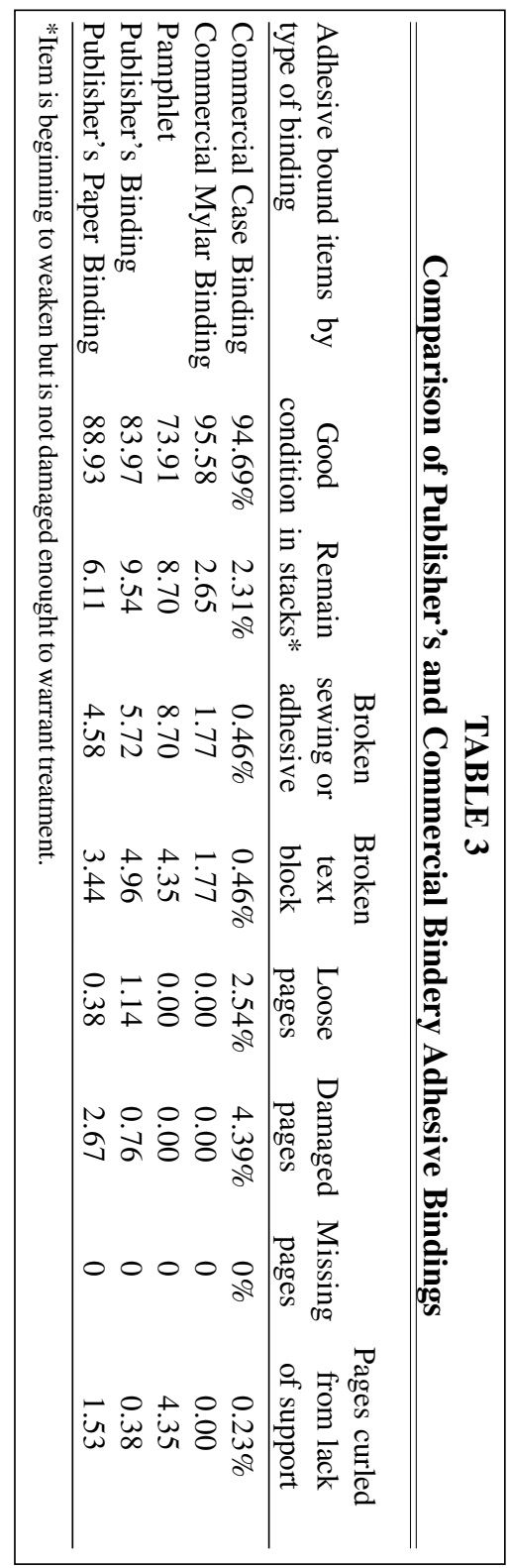

items that have circulated six or more times in the past ten years demonstrates an increasing gap in performance between commercially adhesive-bound volumes and publisher-bound volumes.

\section{Binding Conditions}

Survey results indicate that bindings in
KU's collections, like text blocks, are in good overall condition. A large amount of detail was recorded about the cover of each volume surveyed in an effort to gain as much specific information as possible. This information not only describes the condition of the collections but will also help the Preservation Department develop informed treatment priorities for the collections.

The fourteen scripted answers about the condition of bindings can be classified into three main categories: (1) binding is in good condition; (2) binding has some damage or weakness but not enough to yet warrant treatment and, therefore, the volume can remain in the stacks; and (3) the binding is damaged and needs preservation treatment. Table 4 shows the condition of bindings in the collections based on these three classifications.

The data show that commercially bound volumes hold up much better than publisher bindings. Surprisingly, the data also indicate that publisher paperbound volumes hold up as well as publisher hardbound volumes, a finding not expected by the task force.

\section{Mutilation}

Mutilation is defined as the intentional, although not necessarily malicious, destruction of library materials. Many library users who mutilate materials do not consider the ramifications of their actions. Unfortunately, ignorance does not lessen the effects of their actions.

Table 1 presents a breakdown of the mutilation that was found. These relatively high percentages are alarming. It was known that there was a problem with mutilation, but it was not expected that nearly one in three of all volumes returning from circulation was mutilated. The level of mutilation is even more startling when only those volumes that have circulated six or more times in the past ten years are analyzed, as shown in table 5 . 


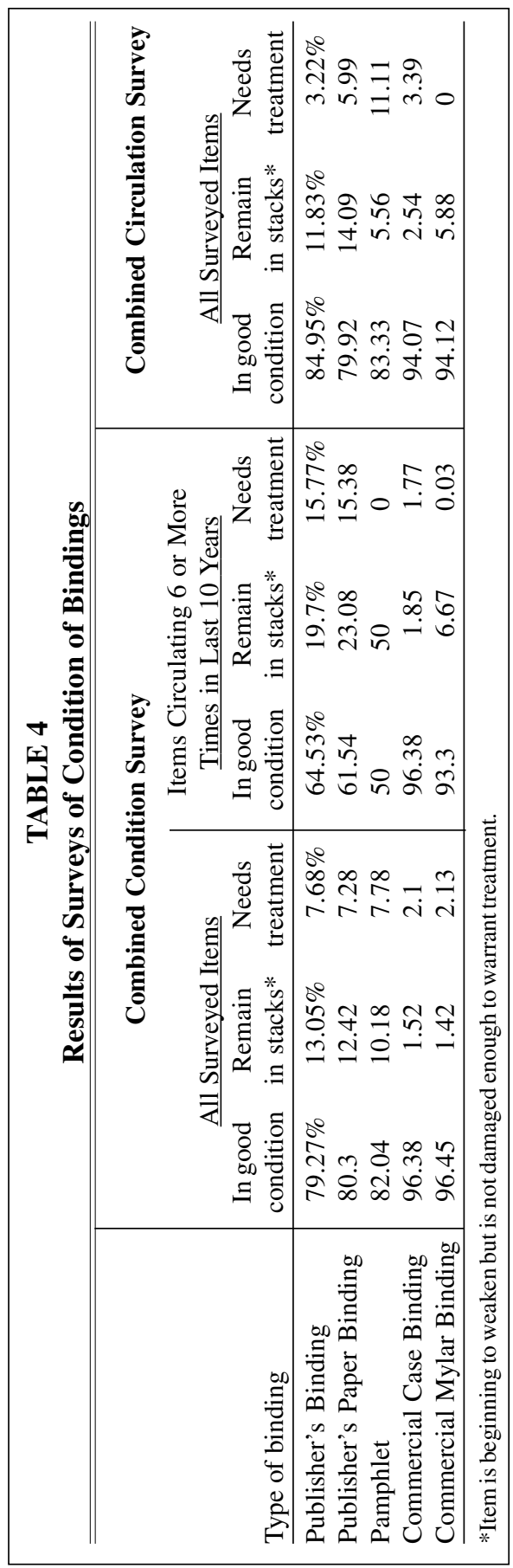

\section{Results and Conclusions}

The KU Libraries were pleased with the data they obtained from their condition surveys. The information gained has proven extremely useful in helping them and the Preservation Department develop a preservation strategy for the collections, and has resulted in the following actions:

- Information on how well paperback volumes hold up to research library patron use and stacks storage resulted in the libraries switching to a paperbackpreferred purchasing profile on many of its approval plans.

- University and library administrators have used information from the report to increase awareness of space and facility concerns throughout the libraries.

- Information was useful in quantifying, in budgetary terms, the preservation needs of the libraries' collections.

- The findings of the condition surveys heightened awareness of preservation issues by stimulating a number of newspaper articles in both campus and local newspapers.

\begin{tabular}{|lc|}
\hline \multicolumn{2}{|c|}{ TABLE 5 } \\
\hline \multicolumn{1}{|c|}{ Mutilation and Patron Damage } \\
\hline \hline Type of Mutilation & Percent \\
\hline Total percentage of volumes & $47.78 \%$ \\
circulated 6 or more times & \\
in past 10 years & \\
Pencil & $28.16 \%$ \\
Ink & 1.85 \\
Highlighter & 4.43 \\
Paper clips & 0 \\
Dog-ears & 13.92 \\
Post-it notes & .95 \\
Bookmarks left in the volume & 4.43 \\
Pages torn or cut out & .95 \\
Animal damage & 0 \\
Pages or cover stained with & 14.87 \\
$\quad$ food, drink, or water \\
\hline
\end{tabular}


Some of the most useful information gained from these condition surveys comes from the smaller survey conducted on materials returning from circulation. The majority of items sent to the Preservation Department for treatment are selected from circulation returns. It was anticipated that materials that circulated were from a different condition population than materials in the stacks. The data show this to be true. This infor- mation has aided the Preservation Department in developing practical treatment policies for materials in the KU Libraries, and in assigning its limited resources to the various treatment options available. Thus, the libraries' goal was obtained of not only gaining general information about their collections, but also gathering practical information that could be used to develop treatment strategies.

\section{Notes}

1. The University of Kansas Libraries consist of seven libraries with combined holdings of more than three million volumes. Although the Law and Medical Libraries work closely with the main library system, they are independent and were excluded from the surveys. The largest and oldest of these libraries - Watson Library - houses nearly one and a half million volumes. Due to the nature of their collections, the nearly 340,000 volumes in the university's archives, special collections, and the Kansas Collections, housed in Spencer Research Library, were not included in the condition surveys.

2. For the purpose of the KU Libraries, paper is classified as "brittle" when it is too weak to withstand a two double-fold test.

3. This is a quote from the Commission on Preservation and Access.

4. Gay Walker et al., "The Yale Survey: A Large-Scale Study of the Book Deterioration in the Yale University Library," College \& Research Libraries 46 (Mar. 1985): 111-32.

5. Tina Chrzastowski et al., "Library Collection Deterioration: A Study at the University of Illinois at Urbana-Champaign," College E Research Libraries 50 (Sept. 1989): 577-84.

6. Randall Bond et al., "Preservation Study at the Syracuse University Library," College $\mathcal{E}$ Research Libraries 48 (Mar. 1987): 132-47.

7. For the condition surveys, the Preservation Task Force defined Northern Europe as Austria, Belgium, Denmark, Finland, France, Germany (West Germany), Great Britain, Greenland, Iceland, Ireland, Luxembourg, Netherlands, Norway, Sweden, and Switzerland.

8. Randall R. Butler, "'Here Today ... Gone Tomorrow': A pH Investigation of Brigham Young University's 1987 Library Acquisitions," College \& Research Libraries 51 (Nov. 1990): 539-51. 